\title{
Effect of Forest Coffee Management Practices on Woody Species Diversity and Composition in Bale Eco-Region, Southeastern Ethiopia
}

\author{
Gonfa Kewessa $^{1}{ }^{*}$, Lemma Tiki², Dejene Nigatu3 ${ }^{3}$, Demeke Datiko ${ }^{4}$ \\ ${ }^{1}$ Department of Forestry, Ambo University, Ambo, Ethiopia \\ ${ }^{2}$ Department of Natural Resource Management, Ambo University, Ambo, Ethiopia \\ ${ }^{3}$ Department of Natural Resource Management, Madda Walabu University, Robe, Ethiopia \\ ${ }^{4}$ Ethiopian Biodiversity Institute, Hawassa Biodiversity Center, Hawassa, Ethiopia \\ Email: ^gonfa.kewessa@gmail.com
}

How to cite this paper: Kewessa, G., Tiki, L., Nigatu, D., \& Datiko, D. (2019). Effect of Forest Coffee Management Practices on Woody Species Diversity and Composition in Bale Eco-Region, Southeastern Ethiopia. Open Journal of Forestry, 9, 265-282. https://doi.org/10.4236/ojf.2019.94015

Received: May 3, 2019

Accepted: August 19, 2019

Published: August 22, 2019

Copyright $\odot 2019$ by author(s) and Scientific Research Publishing Inc. This work is licensed under the Creative Commons Attribution International License (CC BY 4.0).

http://creativecommons.org/licenses/by/4.0/

\begin{abstract}
Forest coffee areas are hotspots areas for conservation of biodiversity due to anthropogenic effect on diversity and abundance of indigenous species. This study was aimed to determine the effect of forest coffee management on woody species diversity and composition. The study was conducted in Dellomena and Harenna Buluk districts where natural forest and forest coffee are found adjacently. Systematic sampling method was used to collect woody species data from 16 transect lines. Eighty (80) sample quadrats of $20 \mathrm{~m} \times 20$ $\mathrm{m}$ quadrat size for mature trees/shrubs and five $5 \mathrm{~m} \times 5 \mathrm{~m}$ subplots within each quadrat for saplings and seedlings were used. Forty-seven species of 29 families and 39 species of 24 families were recorded in natural forest and forest coffee areas respectively. Woody species frequently recorded in most of the sample plots were Celtis africana (100\%), Podocarpus falcatus (95\%), Strychnos mitis (95\%), Diospyros mespiliformis (95\%) and Diospyros abyssinica (90\%) in the natural forest, and Celtis africana (95\%) and Podocarpus falcatus $(95 \%)$ in the forest coffee. Woody species richness $(P=0.000)$, Shannon diversity $(P=0.000)$, Simpson diversity indices $(P=0.02)$ and dominance $(P=0.02)$ were significantly varied between the two forests. This findings revealed significantly higher woody species diversity and richness in natural forest than forest coffee. Negative effects were noticed due to coffee management practices on woody species diversity and composition in forest coffee areas. Hence, reducing the human pressure on forest coffee via awareness raising and training on the effect of coffee management activities and introduction of environmentally friendly forest coffee management techniques are crucial to maintain ecological service and economic benefit of the forest coffee.
\end{abstract}




\section{Keywords}

Biodiversity Conservation, Deforestation, Forest Management, Woody Species Richness

\section{Introduction}

Worldwide significant number of people have encroached natural forests or protected areas to improve their livelihood. Global forest resources in the tropical areas have decreased much over the last century (Priess et al., 2007). Tropical forests are among species-rich ecosystems that have been negatively influenced at very high rates (Myers, 2000). Tropical forest ecosystem comprises diverse fauna and flora species. The existence of diverse species of plants delivers resources and serves as a home for all species (Barbier et al., 2008). Degradation and deforestation of tropical forests resulted in decline in global biodiversity (Heywood, 1995). Many forest resources in the globe have been over exploited and resulted in difficulties to enhance and conserve native woody species diversity (Brown \& Boutin, 2009; Emmanuel, 2011; Nigatu et al., 2017). Similarly, Ethiopian forest ecosystems are severely threatened by agricultural land expansion, wood exploitation, overgrazing and establishment of new settlements in the forested lands (Good, 2004; Senbeta \& Denich, 2006; Motuma et al., 2008). Gole et al. (2002) has also reported deforestation rate of 10,000 ha per year in the coffee growing areas in the Southwest Ethiopia. Expansions of coffee cultivation have also resulted in biodiversity loss in Ethiopia (Anonymous, 2010).

Large forest areas in the Ethiopia are found in the major coffee growing areas, including the Harenna forest in Bale (Gole \& Senbeta, 2008). These forest areas have already been globally recognized as hotspot areas for biodiversity conservation (Mittermeier et al., 2005) because of the challenging anthropogenic threats to plant and animal species and their biodiversity composition. According to Valencia (2015), coffee agroforestry may be particularly significant for conserving trees of conservation concern and late-successional stage. The original habitat of forest coffee has been promoted as a means for preserving biodiversity in the tropics (Ambinakudige \& Sathish, 2009). Indigenous shade trees for coffee production are very common features in coffee production systems of afromontane rainforests (Gole \& Senbeta, 2008). Recent studies on some coffee forests of Ethiopia also showed that coffee forests are rich in plant species diversity (Gole, 2003; Schmitt \& Grote, 2006; Senbeta, 2006; Gole et al., 2008). Over 700 plants species were recorded in Bale, Bonga, Sheko and Yayu, which represents about $10 \%$ of the countries flora (Gole \& Senbeta, 2008).

Despite of socioeconomic and ecological importance, expansion of agricultural land and establishment of coffee plantation in Ethiopia negatively affect forests coffee (Gole \& Senbeta, 2008) by destroying and degrading woody plant species (Silva et al., 2008; Laurance, 2010; Mebrat \& Gashaw, 2013). Moreover, 
selective cutting of valuable shade tree species for timber production and reducing shade intensity have also depleted woody plant species from the afromontane rainforests (Perfecto et al., 2005; Yadessa et al., 2008). Moreover, conversion of a forest coffee system into a semi-forest coffee system affects the floristic composition and diversity of plant species (Gole, 2003; Senbeta, 2006; Tesfaye, 2006; Schmitt \& Grote, 2006).

In Bale Eco-region, the local communities living in and around the forest mainly derive their livelihoods from forests coffee (Senbeta, 2006). Coffee is grown inside the forest by removing competing undergrowth vegetation and some canopy trees (Teketay, 1999; Gole \& Senbeta, 2008). Slashing of understory vegetation and thinning of shade trees are a common practice in forest coffee growing areas of Bale Eco-region. This may affects diversity of woody plant species to the extinction and challenges sustainable management of resources in the forest coffee. The loss of biodiversity and the changing pattern of woody species have necessitated the assessment of woody species diversity (Pant \& Samant, 2007; Tolera et al., 2008; Mebrat \& Gashaw, 2013).

Many studies determined woody species diversity in undisturbed ecosystems and/or agricultural ecosystems of the world but less attention was given to evaluation of effect of forest coffee management practices on plant species diversity and composition in the global hotspot area for biodiversity conservation (Moguel \& Toledo, 1999). Specifically, scanty of information exist about woody species diversity and composition in forest coffee areas of afromontanae forest of tropical Africa (Komar, 2006; Senbeta, 2006; Gole \& Senbeta, 2008). Some of the studies conducted in some parts of Ethiopia on coffee management and its impact on woody species include Hundera et al. (2013) and Kumsa et al. (2016). Indeed, this study aimed to determine the effect of forest coffee management on woody species diversity and composition in Harenna forest of Bale Eco-region, Southeastern Ethiopia.

\section{Materials and Methods}

\subsection{Study Area}

The study was conducted in Dellomena and Harenna Buluk districts of Bale Eco-region in Southeast Ethiopia (Figure 1). The study area is characterized by bimodal rainfall with mean annual rainfall of $850 \mathrm{~mm}$ and mean annual temperature of $18^{\circ} \mathrm{C}$ (Gole \& Senbeta, 2008). It encompasses flatlands; moderately steep rolling hills with valley bottoms and waterways. Harenna forest is the largest montane forest in the study eco-region (Senbeta \& Denich, 2006; Gole \& Senbeta, 2008). It supports over 300 plant species with many endemic plant species (Senbeta, 2006). The unique floristic composition includes Podocarpus falcatus, Ocotea kenyensis, Filicium decipiens and Warburgia ugandensis. Forest coffee occurs between 1300 and 1850 meter above sea level of Harenna forest and dominated by woody species and the understory coffee plants. Majority of the populations in the two districts are settled in the lower southern edging of the 


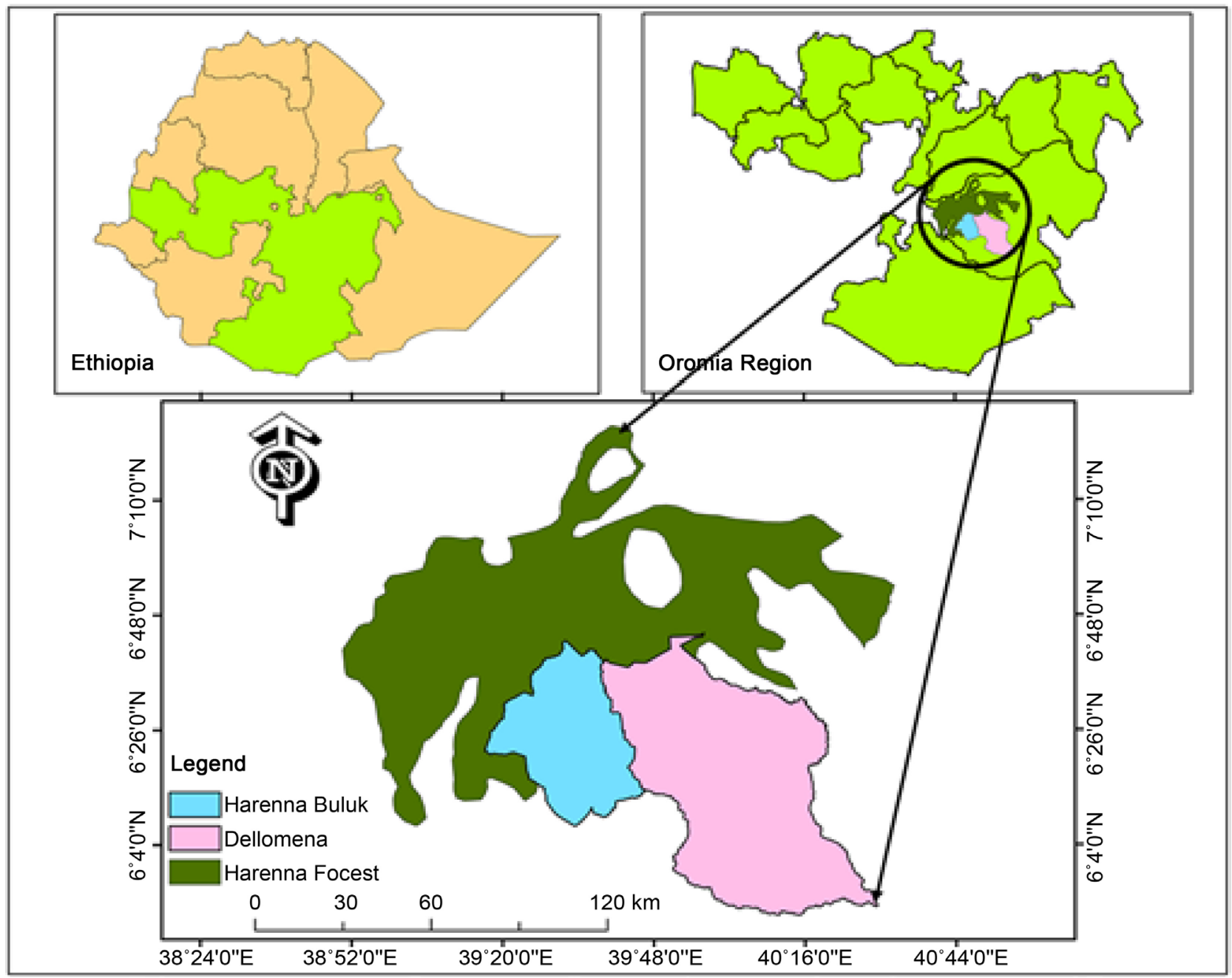

Figure 1. Map of the study area with the map of Ethiopia.

forest and some even in the forest. All people in the study area have coffee plots and beehive, and graze their livestock's in the forest. Their livelihoods mainly depend on forest exploitation, crop and livestock production, and collection of non-timber forest products (Gole \& Senbeta, 2008).

\subsection{Sampling Techniques}

First a reconnaissance survey was made to collect baseline information and to observe vegetation distribution of forests coffee and adjacent natural forest in Harenna Buluk and Dellomena districts. Two sites that encompass both forest coffee and adjacent natural forests were selected purposely from each district. Then, 16 transect lines with $1200 \mathrm{~m}$ average length were laid out in both forest coffee and adjacent natural forest. Five main plots of $20 \mathrm{~m} \times 20 \mathrm{~m}$ were established on each transect line at interval of $200 \mathrm{~m}$. Forty main plots with a total area of 1.6 ha were established in each forest types to identify woody species. This method was developed in line with Gole (2003). Saplings and seedlings were identified in five subplots of $5 \mathrm{~m} \times 5 \mathrm{~m}$ within each main plot for each for- 
est type. Accordingly, 80 main plots $(20 \mathrm{~m} \times 20 \mathrm{~m})$ and 400 subplots $(5 \mathrm{~m} \times 5 \mathrm{~m})$ were laid in the two forest types with the total area of 3.2 ha. From reconnaissance survey, the total sampled area was assumed to be representative considering that both forest types are under uniform topographical conditions, altitudinal range and woody species distribution.

\subsection{Data Collection Methods}

Individuals of woody plant species with diameter at breast height (DBH) of larger than $5 \mathrm{~cm}$ were identified and counted in the main plots. Saplings (individuals with DBH from 5 to $2.5 \mathrm{~cm}$ and height greater than $1 \mathrm{~m}$ ), and seedlings (individuals with height $\leq 1 \mathrm{~m}$ and $\mathrm{DBH}$ less than $2.5 \mathrm{~cm}$ ) were identified and counted within the subplots. Diameter measurements for trees and sapling/seedlings were taken at breast height $(1.3 \mathrm{~m})$ and at root collar by using caliper and diameter tape, respectively following (Senbeta \& Teketay, 2001). For trees branched below $1.3 \mathrm{~m}, \mathrm{DBH}$ measurement of each branch was taken independently. Hypsometer and graduated stick were used for height measurements. Geographic location and elevation of each plots was taken using GPS. All woody species in the sample plots were identified by scientific name using the modern Flora of Ethiopiaand Eritrea (Friis, 2009). Moreover, forest coffee management practices were identified through transect walk and key informants' interviews. For key informants' interview 12 elderly people who are knowledgeable about the forest resource in the study site were involved.

\subsection{Data Analysis}

Shannon-Wiener Diversity Index $\left(H^{p}\right)$ was used to determine floristic composition of forest coffee and adjacent natural forest (Shannon \& Weaver, 1948). Evenness or Equitability index (E) was determined to measure of evenness (Krebs, 1999). Species richness was determined by converting the average number of species in forest coffee and adjacent natural forest into hectare bases, and expressed as number of species per hectare. Simpson's diversity index was determined (Magurran, 1988). Sørensen's Similarity Index $(\beta)$ was used to evaluate floristic similarity between forest coffee and natural forest (Sørensen, 1948). Density of woody plants in each forest types was determined as number of individual per hectare. Then, the variation in woody species richness, dominance, and Simpson, Shannon and Equitability indices between forest coffee and adjacent natural forest was tested by using independent $\mathrm{t}$-test at $95 \%$ significance level by using SPSS statistical Software version 20.0.

\section{Results and Discussion}

\subsection{Traditional Forest Coffee Management Practices}

Key informants reported that they have collected non-timber forest products like honey, medicinal plants and coffee from the natural forest. However, they have only the right to sell pole of felled trees to Bale Forest and Wildlife Enterprise 
and utilize for household consumption. As a result, dwellers mainly managed forest coffee areas to increase productivity of coffee plants through slashing of bushes and herbs, thinning of trees through cutting/debarking of stems and cultivation of the land. They also confirmed that lians, herbs, shrubs and trees were cleared from forest coffee areas to reduce the competition of these vegetation with wild coffee plants and to ease management and harvesting of coffee. Similarly, Gole and Senbeta (2008) reported that during opening up phase; small trees, shrubs, and herbaceous vegetation competing with coffee are totally cleared without preferential even for endemic or threatened species. KIs also declared that they slash herbs, tree/shrub seedlings to reduce their competition with understory coffee before the commencement of rainy season and coffee harvesting operation. Moreover, KIs indicated that the productivity of coffee increases as the density of shade trees decrease. This result agrees with Beer et al. (1998), and Faminow and Rodriguez (2001) who revealed that un-shaded systems could produce greater coffee yields. Key informants also reported that they practiced thinning of large trees to allow exposure of coffee plants to solar radiation. However, the canopies of the remaining trees expand, and gradually close up after some years to the level that can highly reduce coffee production. Reduction of shade through killing shade trees is common practice in the forest coffee areas even if it is not allowed legally. Key informants clearly depicted that they gradually cleared other woody plant species and retain only those tree species that they believe to increase coffee productivity. Cordia africana, Croton macrostachyus, Millettia ferruginea, Ekebergia capensis, Podocarpus falcatus, Pouteria adolfi-friederici, Diospyros abyssinica, Olea capensis, and Olea welwitschii are trees species preferred by farmers for coffee shade (Gole \& Senbeta, 2008).

It was observed that larger trees were killed furtively as cutting trees is prohibited in forest coffee areas. Key informants declared that most of forest dwellers have killed large trees through debarking of their stem and cutting of their main roots below or at ground level. A key informant amazingly expressed how secretly he killed large trees as "I dug an elbow pit around a large tree, cut its main roots, removed barks of the stem, returned back the soil into the pit and cover it with partially decomposed organic matter. How one can identify what I did? Thus, the trees seam naturally dead or felled.". Similarly, Mengist et al. (2013) revealed that cutting tree and tree ringing were practiced in forest coffee of Belete Gera Forest. Hoeing/cultivation is an emerging practice in the forest coffee system to facilitate good rooting condition for coffee plants and to avoid competing understory vegetation. Key informants declared that hoeing was first practiced by illegal settlers in the forest and gradually adopted by others. Key informants also indicated that coffee management activities like hoeing and slashing have negative effects on diversity of woody and non-woody plant species.

\subsection{Woody Species Composition}

There are 30 families identified in natural forest and forest coffee (Table 1 and 
Table 1. Family and woody plant species in natural forest and forest coffee.

\begin{tabular}{|c|c|c|c|c|c|c|c|c|c|}
\hline \multirow{3}{*}{ Family } & \multicolumn{4}{|c|}{ Woody plant species in } & \multirow{3}{*}{ Family } & \multicolumn{4}{|c|}{ Woody plant species in } \\
\hline & \multicolumn{2}{|c|}{ Natural Forest } & \multicolumn{2}{|c|}{ Forest Coffee } & & \multicolumn{2}{|c|}{ Natural Forest } & \multicolumn{2}{|c|}{ Forest Coffee } \\
\hline & No & $\%$ & No & $\%$ & & No & $\%$ & No & $\%$ \\
\hline Anacardiaceae & 1 & 2.13 & 1 & 2.56 & Meliaceae & 0 & 0.00 & 1 & 2.56 \\
\hline Apocyanceae & 1 & 2.13 & 0 & 0.00 & Melianthaceae & 1 & 2.13 & 1 & 2.56 \\
\hline Araliaceae & 1 & 2.13 & 1 & 2.56 & Moraceae & 2 & 4.26 & 1 & 2.56 \\
\hline Astraceae & 1 & 2.13 & 1 & 2.56 & Myrsinaceae & 1 & 2.13 & 0 & 0.00 \\
\hline Boraginaceae & 1 & 2.13 & 2 & 5.13 & Myrtaceae & 2 & 4.26 & 1 & 2.56 \\
\hline Canellaceae & 1 & 2.13 & 1 & 2.56 & Oleaceae & 4 & 8.51 & 3 & 7.69 \\
\hline Capparidaceae & 1 & 2.13 & 0 & 0.00 & Podocarpaceae & 1 & 2.13 & 1 & 2.56 \\
\hline Celastraceae & 1 & 2.13 & 0 & 0.00 & Rhamnaceae & 1 & 2.13 & 0 & 0.00 \\
\hline Combretaceae & 1 & 2.13 & 1 & 2.56 & Rhizophoraceae & 1 & 2.13 & 1 & 2.56 \\
\hline Ebenaceae & 3 & 6.38 & 2 & 5.13 & Rubiaceae & 4 & 8.51 & 4 & 10.26 \\
\hline Euphorbiaceae & 2 & 4.26 & 1 & 2.56 & Rutaceae & 4 & 8.51 & 4 & 10.26 \\
\hline Fabaceae & 2 & 4.26 & 2 & 5.13 & Salvadoraceae & 1 & 2.13 & 0 & 0.00 \\
\hline Icacinaceae & 1 & 2.13 & 1 & 2.56 & Sapindaceae & 2 & 4.26 & 3 & 7.69 \\
\hline Lauraceae & 1 & 2.13 & 1 & 2.56 & Sapotaceae & 1 & 2.13 & 1 & 2.56 \\
\hline Loganiaceae & 2 & 4.26 & 2 & 5.13 & Ulmaceae & 2 & 4.26 & 2 & 5.13 \\
\hline Total & & & & & & 47 & 100 & 39 & 100 \\
\hline
\end{tabular}

Table 2), respectively. Of which Oleaceae, Rutaceae and Rubiaceae were the plant families that contain large number of woody species in the natural forest, each represented by four species. The Ebenaceae family was represented by three woody species in natural forest. In forest coffee, Rutaceae and Rubiaceae were the dominant families in terms of number of woody species in which each were represented by four species. Oleaceae and Sapindaceae were the next dominant families with three species each in forest coffee. Apocyanceae, Capparidaceae, Celastraceae, Myrsinaceae, Rhamnaceae and Salvadoraceae were families with shrub life forms which were not found in forest coffee areas (Table 1). This indicates that shrub species were cleared from forest coffee to reduce competition with coffee plants. Similarly, clearing of shrubs in forest coffee areas was reported in Harenna forest and in Belete Gera Forest (Gole \& Senbeta, 2008; Mengist et al., 2013).

Forty-seven woody plant species belonging to 29 families were identified in natural forest (Table A1), whereas, 39 woody plant species belonging to 24 families are identified in forest coffee (Table A2). Celtis africana, Diospyros mespiliformis, Podocarpus falcatus, Strychnos mitis, Diospyros abyssinica, Filicium decipiens, Teclea nobilis, Cassipourea malosana, Galiniera saxifraga and Coffea arabicawere frequently observed in the natural forest. In forest coffee, Coffea arabica, Celtis africana, Podocarpus falcatus, Diospyros mespiliformis, Strychnos miti and Diospyros abyssinica were frequently observed woody species. The absolute frequency of Filicium decipiens, Teclea nobilis and Olea welwitschii 
Table 2. Woody species composition in natural forest and forest coffee, and their absolute frequency (Note; NF = Natural forest, $\mathrm{FC}=$ Forest coffee, NA $=$ Not Available, $\mathrm{T}=$ Tree, and TS $=$ Tree or Shrub $)$.

\begin{tabular}{|c|c|c|c|c|c|}
\hline \multirow{2}{*}{ Species Name } & \multirow{2}{*}{ Family Name } & \multirow{2}{*}{ Local Name } & \multirow{2}{*}{$\begin{array}{l}\text { Life } \\
\text { form }\end{array}$} & \multicolumn{2}{|c|}{ Absolute Frequency (\%) } \\
\hline & & & & NF & FC \\
\hline Acalypha volkensii pax & Euphorbiaceae & Fuho & TS & 25 & NA \\
\hline Allophylus abyssinicus & Sapindaceae & Arjo & $\mathrm{T}$ & NA & 10 \\
\hline Apodytes acutifolia & Icacinaceae & Mewa & $\mathrm{T}$ & 30 & 5 \\
\hline Avophaylus abyssinica & Sapindaceae & Obora & $\mathrm{T}$ & 5 & 5 \\
\hline Bersama abyssinica Fresen. & Melianthaceae & Horoqa & $\mathrm{T}$ & 15 & 25 \\
\hline Buddleia polystachya & Loganiaceae & Dhadhatu & $\mathrm{T}$ & 50 & 5 \\
\hline Calpurnia aurea (Ait.) Benth. & Fabaceae & Cekata & S & 30 & 15 \\
\hline Capparis tomentosa & Capparidaceae & Arangama & S & 20 & NA \\
\hline Carissa spinarum $L$. & Apocyanceae & Hagamsa & S & 20 & NA \\
\hline Cassipourea malosana (Baker) Alston & Rhizophoraceae & Tilo & $\mathrm{T}$ & 65 & 45 \\
\hline Celtis africana Burm.f. & Ulmaceae & Mataqoma & $\mathrm{T}$ & 100 & 95 \\
\hline Citrus aurantium & Rutaceae & Arbo/Irba & TS & 55 & 20 \\
\hline Coffea arabica $L$. & Rubiaceae & Buna & S & 60 & 100 \\
\hline Cordia africana Lam. & Boraginaceae & Wadessa & $\mathrm{T}$ & NA & 5 \\
\hline Crotolaria agatiflora Schweinf. Sub.sp. Erlangeri Bak. F. & Fabaceae & Shashamane & S & 10 & 15 \\
\hline Croton macrostachyus Del. & Euphorbiaceae & Makanisa & $\mathrm{T}$ & 25 & 50 \\
\hline Diospyros abyssinica (Hiern) F. White & Ebenaceae & Loko adi & TS & 90 & 80 \\
\hline Diospyros mespiliformis Hochst. Ex A.DC & Ebenaceae & Loko guracha & $\mathrm{T}$ & 95 & 85 \\
\hline Dobera glabra & Salvadoraceae & Hara & TS & 10 & NA \\
\hline Ehretia cymosa Thonn. & Boraginaceae & Ulaga & $\mathrm{T}$ & 60 & 50 \\
\hline Euclea racemosa Murr.subsp. schimperi $(A . D C$. $)$ White & Ebenaceae & Miesa & $\mathrm{T}$ & 5 & NA \\
\hline Fagaropsis angolensis (Engl.) Milne & Rutaceae & Sisa & $\mathrm{T}$ & 15 & 10 \\
\hline Ficus sur Forssk. & Moraceae & Harbu & $\mathrm{T}$ & 5 & NA \\
\hline Ficus sycomorus & Moraceae & Lugo & $\mathrm{T}$ & NA & 5 \\
\hline Ficus thonningii Blume & Moraceae & Dembi & $\mathrm{T}$ & 5 & NA \\
\hline Filicium decipiens (Wight \& Am.) Thw. & Sapindaceae & Cana & $\mathrm{T}$ & 75 & 25 \\
\hline Galiniera saxifraga ( $G$. coffeoides) & Rubiaceae & Jaldae & $\mathrm{T}$ & 65 & 50 \\
\hline $\begin{array}{l}\text { Maytenus gracilipes (Welw.ex Oliv.) Exell subsp. Arguta } \\
\text { (Loes.) }\end{array}$ & Celastraceae & Kombolcha & TS & 30 & NA \\
\hline Mimusops kummel A. DC. & Sapotaceae & Qolati & $\mathrm{T}$ & 20 & 35 \\
\hline Myrsine africana & Myrsinaceae & Baco/qacama & S & 5 & NA \\
\hline Ocotea kenyensis (Chiov.) Robyns \& Wilczek & Lauraceae & Gigicha & $\mathrm{T}$ & 55 & 25 \\
\hline Olea capensis L. ssp. Macrocarpa (C. H. Wright) Verdc. & Oleaceae & Segida & $\mathrm{T}$ & 15 & NA \\
\hline Olea capensis subsp. hochstetteri (Bak.) P.S. Friis & Oleaceae & Onoma & $\mathrm{T}$ & 65 & 75 \\
\hline Olea welwitschii (Knobl.) Gilg \& Schellenb. & Oleaceae & Gagama & $\mathrm{T}$ & 65 & 5 \\
\hline Podocarpus falcatus (Thunb.) R. B. ex. Mirb & Podocarpaceae & Birbirsa & $\mathrm{T}$ & 95 & 95 \\
\hline Polyscias fulva (Hiern) Harms & Araliaceae & Koriba & $\mathrm{T}$ & 5 & 10 \\
\hline Psydrax schimperiana (A. Rich.) Bridson & Rubiaceae & Galo & $\mathrm{T}$ & 65 & 55 \\
\hline
\end{tabular}




\begin{tabular}{|c|c|c|c|c|c|}
\hline Rhamnus prinoides L. Herit. & Rhamnaceae & Gesho & TS & 45 & NA \\
\hline Rhus ruspolii Engl. & Anacardiaceae & Hirqe & TS & 20 & 30 \\
\hline Rothmannia urcelliformis (Hiern.) Robyns & Rubiaceae & Bulala & $\mathrm{T}$ & 60 & 40 \\
\hline Schrebera alata (Hochst.) Welw. & Oleaceae & Dhamae & $\mathrm{T}$ & 10 & 5 \\
\hline Strychnos mitis S. Moore & Loganiceae & Mulka & $\mathrm{T}$ & 95 & 85 \\
\hline Strychnos spinosa & Myrtaceae & Gotu & $\mathrm{T}$ & 5 & NA \\
\hline Syzygium guineense & Myrtaceae & Badessa & $\mathrm{T}$ & 40 & 35 \\
\hline Teclea nobilis Del. & Rutaceae & Hadhesa & $\mathrm{T}$ & 70 & 25 \\
\hline Terminalia laxilora & Combretaceae & Dabaqa & $\mathrm{T}$ & 30 & 15 \\
\hline Trema guineensis (Schumach. \& Thonn.) & Ulmaceae & Hagala & $\mathrm{T}$ & 5 & 5 \\
\hline Trichilia emetica ( T. roka) & Meliaceae & Anonu & $\mathrm{T}$ & NA & 5 \\
\hline Vepris dainellii (Pichi-Serm.) Kokwaro & Rutaceae & Arabe & TS & 60 & 20 \\
\hline Vernonia leopoldi (Sch. Bip. ex walp.) Vatke & Astraceae & Reji & S & 10 & 15 \\
\hline Warburgia ugandensis Sprague & Canellaceae & Befti & $\mathrm{T}$ & 60 & 55 \\
\hline
\end{tabular}

recorded in the adjacent natural forest were reduced from $75 \%$ to $25 \%, 70 \%$ to $25 \%$ and $65 \%$ to $5 \%$ in the forest coffee. However, its value increased in the case of Coffea arabica and Croton macrostachyus from $60 \%$ to $100 \%$ and from 25 to $50 \%$ respectively. This implies that abundance of coffee and some shade tree species were increased by reducing other woody species that thereof affect woody species composition in forest coffee. Similarly, retention or planting of preferable shade tree species and clearance of other species were reported in coffee forest and plantations in different part of the world (Ambinakudige \& Sathish, 2009; Mengist et al., 2013; Likassa, 2014).

The species richness of natural forest and forest coffee were $19 \pm 0.9$ and $12.55 \pm$ 0.73 respectively (Table 1$)$. It showed significant difference $(P=0.001)$ between forest coffee and adjacent natural forest. The above results indicate that more woody species were found in adjacent natural forest as compared to the forest coffee. Similarly, research findings of Ambinakudige and Sathish (2009), Hylander and Sileshi (2009) and Likassa (2014) revealed higher tree species diversity in adjacent natural forests than in shade coffee farms. The effect of coffee management practices has affected negatively woody species diversity and richness in the forest coffee. Moreover, local people retained only selected shade trees as over storey trees in the system. Similarly, Wassie et al. (2009) also declared the negative effect human induced disturbance on species diversity in forest coffee.

\subsection{Life Form of Woody Species in Forest Coffee and Adjacent Natural Forest}

Tree is the dominant life form of woody species in the natural forest and forest coffee. Tree constituted $63.5 \%$ and $71.4 \%$ of woody species in natural forest and forest coffee, respectively. Shrubs are the co-dominant life form of woody species, which contributes $11.91 \%$ and $11.54 \%$ in natural and forest coffee, respec- 
tively. This greater percentage of tree life form in forest coffee is due to retention of shade trees in the system.

\subsection{Woody Species Diversity}

The Simpson diversity index of $0.84 \pm 0.012$ and $0.74 \pm 0.039$, and Shannon diversity index of $2.15 \pm 0.072$ and $1.74 \pm 0.098$ were obtained in natural forest and forest coffee respectively (Table 3). Similarly, Mengist et al. (2013) found higher Shannon diversity index in forest without coffee (2.98) than in the forest with coffee (2.13). Senbeta and Denich (2006) found higher Shannon diversity index of 2.82 and 2.6 at Bebeka forest coffee and Harenna forest coffee respectively. Both Simpson $(P=0.02)$ and Shannon $(P=0.00)$ have significant higher value in natural forest than forest coffee in this study. These indicate that coffee management practices resulted in lower woody species diversity in forest coffee. Similarly, Engida and Teshome (2012) revealed that forests with low levels of disturbance have high species diversity as compared to disturbed forest. The above results imply that management of coffee forests has affected and will continue to affect the diversity of woody species in the forests. Similarly, Kufa (2006) reported that as coffee management continues, the coffee forest could be changed to coffee farms with a few shade trees.

Dominance of $0.26 \pm 0.039$ and $0.16 \pm 0.012$ were recorded in the forest coffee and adjacent natural forest respectively. The significantly $(P=0.02)$ higher value of dominance in forest coffee indicated presence of large number of individuals of few species. This variation in dominance may come from different management intervention undertaken in forest coffee like slashing, hoeing, weeding and human interferences. Similarly, Wassie et al. (2009) and Mekuria and Aynekulu (2011) indicated that human induced disturbance have a strong negative effect on species composition, seed germination, seedling growth, and mortality of many of the plant communities and in turn results in less species richness. Schmitt et al. (2009) also indicated that management interventions in semi-forest coffee shown a strong impact on tree species composition. Moreover, Walters et al. (2006) indicated that land use change affects the composition, diversity and distribution pattern of vegetation. Species equitability/evenness indices of natural forest and coffee forest were $0.73 \pm 0.02$ and $0.69 \pm 0.04$ respectively (Table 3 ). This indicates that about $70 \%$ of woody species are equally

Table 3. Woody species diversity indices in natural forest and forest coffee.

\begin{tabular}{cccccc}
\hline \multirow{2}{*}{ Land use } & Richness & Dominance & Simpson & Shannon & Equitability \\
\cline { 2 - 6 } & $19 \pm 0.9$ & $0.16 \pm 0.012$ & $0.84 \pm 0.012$ & $2.15 \pm 0.072$ & $0.73 \pm 0.02$ \\
\hline $\begin{array}{c}\text { Natural } \\
\text { forest }\end{array}$ & $12.55 \pm 0.73$ & $0.26 \pm 0.039$ & $0.74 \pm 0.039$ & $1.74 \pm 0.098$ & $0.69 \pm 0.04$ \\
$\begin{array}{c}\text { Forest } \\
\text { coffee }\end{array}$ & 0.000 & 0.02 & 0.02 & 0.000 & 0.27 \\
$P$-value & & & & & \\
\hline
\end{tabular}


available and distributed in both natural forest and forest coffee. Wilson et al. (1996) also revealed that a higher value of evenness indicates that most species are present with relatively equal individuals in a community. Moreover, Magurran (2004) indicated that the evenness measure of 1 revealed being complete evenness in a community.

\subsection{Variation in Woody Species Composition between Natural Forest and Forest Coffee}

Sørensen’s similarity index of 0.814 was found for natural forest and forest coffee. This implies that more woody species overlap between the two ecosystems. Similarly, Sørensen (1948) revealed that Sørensen's similarity index of 0 indicates there is no species overlap between the communities and a value of 1 indicates exactly the same species are found in both communities. The finding of this study also agrees with the findings of Hylander and Sileshi (2009) and contradicts with the finding of Mendez et al. (2007).

Of 51 woody species identified in both forest types, 35 species $(68.6 \%)$ were common to both forest types. However, $12(23.5 \%)$ and 4 (7.9\%) were unique to the natural forest and forest coffee respectively. This implies natural forest contains comparatively more unique woody species than the adjacent forest coffee. This agrees with the results of Likassa (2014) which reported presence of more unique species in natural forest as compared to forest coffee.

\subsection{Occurrence Frequency of Woody Species}

Frequency of occurrence of the species across sample plots varies between natural forest and forest coffee (Figure 2 and Figure 3). Five species in the natural forest and two species in forest coffee had an absolute frequency greater than $90 \%$. Those species in natural forest include Celtis africana (100\%), Podocarpus

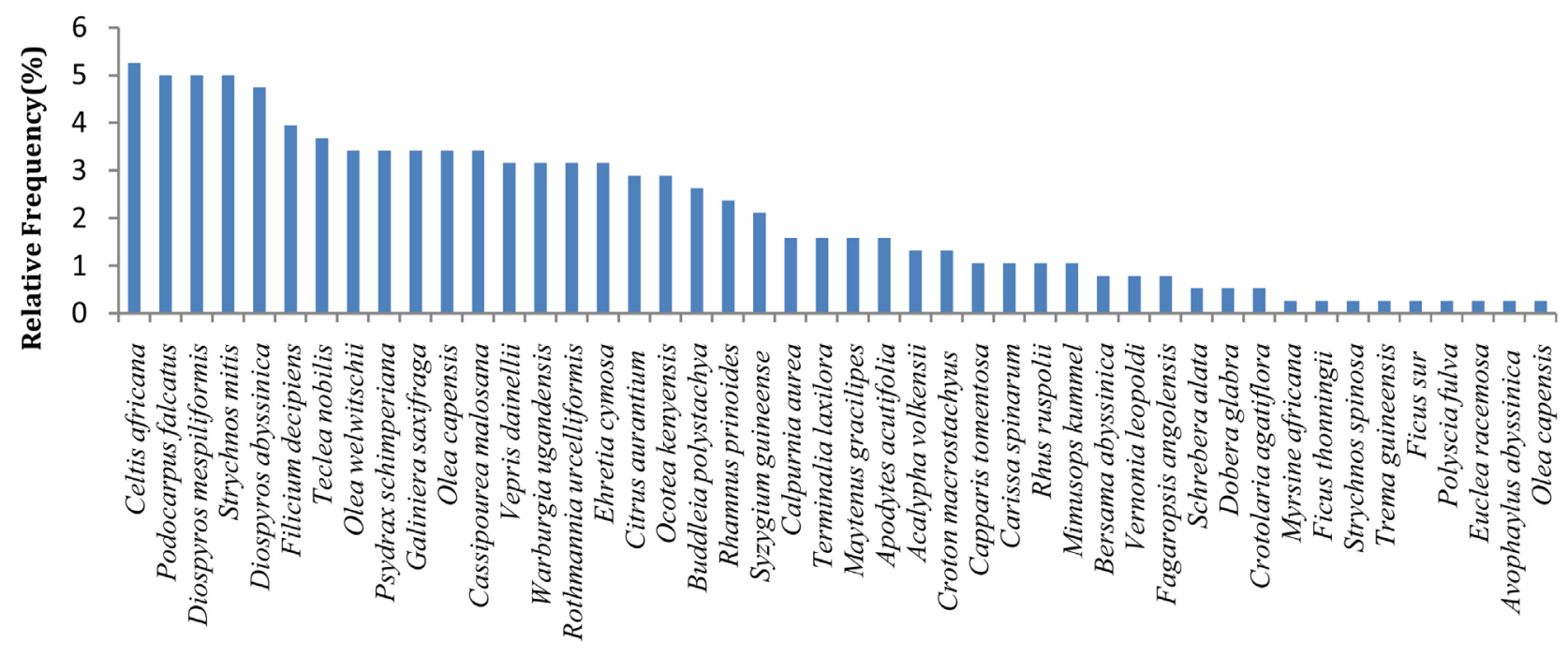

\section{Species Name}

Figure 2. Frequency of woody species natural forest. 


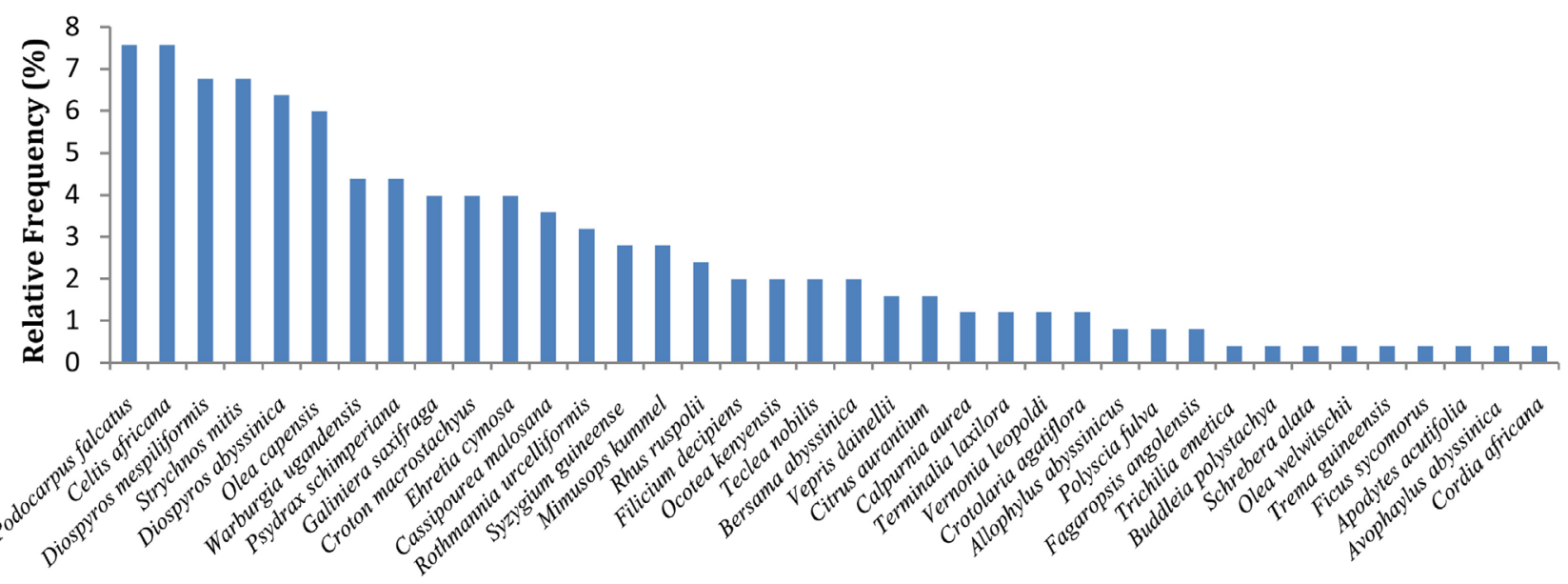

Species Name

Figure 3. Frequency of woody species forest coffee.

falcatus (95\%), Strychnos mitis (95\%), Diospyros mespiliformis (95\%) and Diospyros abyssinica (90\%) while those of forest coffee includes Celtis africana (95\%) and Podocarpus falcatus (95\%). Furthermore, 20 species in the natural forest and 11 in the forest coffee were occurred in more than half (50\%) of the total plots investigated. This implies that large number of species were recorded in few quadrats.

Smaller number of tree species frequently observed in forest coffee as compared to the adjacent natural forest. This is due to, the traditional management of shade tree in Ethiopia is to reduce tree density and understory vegetation to improve the production of coffee while maximizing the use of selected tree species (Aerts et al. 2011). Farmers selectively remove some tree species through various management techniques, including selection of tree species with desirable properties (Asfaw, 2003; Abebaw, 2006). For this reason, only few shade tree species with a greater economic or ecological value (shade) or both dominated the coffee-based forest system in the Harenna forest.

\section{Conclusion}

Dellomena and Harenna Buluq districts of Bale Eco-region endowed large area of forest coffee. The livelihoods of most of peoples in the districts are largely dependent on forest coffee. Local communities have practiced slashing understory vegetation, thinning of large trees and hoeing in forest coffee areas to improve productivity of coffee plants. As a result, woody species richness, Shannon diversity, Simpson diversity indices and dominance were significantly varied between the two forests. These findings revealed significantly higher woody species diversity and richness in natural forest than forest coffee. These results could confirm that coffee management practices have significantly reduced composition, diversity and evenness of woody species in forest coffee. Negative effects were noticed due to coffee management practices on woody species diversity and 
composition in forest coffee areas. This maximization of productivity of coffee in expense of the indigenous woody species might silently eradicate the remnant Afromontane forest and biodiversity in the study area if not timely and well addressed. Therefore, it is compulsory to maximize the benefit of growing population from forest coffee through introducing compatible alternative income sources like modern honeybee production and others that minimize reliance on coffee in a way that it can balance conservation and utilization of natural resources. To this end, reducing the human pressure on forest coffee via awareness raising and training on the effect of coffee management activities and introduction of environmentally friendly forest coffee management techniques are crucial to maintain ecological service and economic benefit of the forest coffee.

\section{Acknowledgements}

The authors are grateful to Madda Walabu University and FARM Africa for financial support for the research work. The authors also thank Dellomenna and Harenna Buluk districts Pastoral Development Office for their cooperation during the field work. They also acknowledge the development agents for their cooperation and those people who provided their supports directly or indirectly for the successful accomplishment of this research.

\section{Conflicts of Interest}

The authors declare no conflicts of interest regarding the publication of this paper.

\section{References}

Abebaw, Z. (2006). Farmers' Indigenous Knowledge in Managing Agroforestry Practices in Lay Gayint District, South Gonder Zone, Ethiopia. M.Sc. Thesis, Hawassa: Hawassa University, Wondo Genet College of Forestry and Natural Resource.

Ambinakudige, S., \& Sathish, B. N. (2009). Comparing Tree Diversity and Composition in Coffee Farms and Sacred Forests in the Western Ghats of India. Biodiversity Conservation, 18, 987-1000. https://doi.org/10.1007/s10531-008-9502-5

Anonymous (2010). The Implications of Deforestation in Ethiopia.

Asfaw, Z. (2003). Tree Species Diversity, Top Soil Conditions and Arbuscular Mycorrhizal Association in the Sidama Traditional Agroforestry Land Use, Southern Ethiopia. Ph.D. Thesis, Department of Forest Management and Products, SLU. Acta Universitatis Sueciae, Silverstria.

Barbier, S., Gosselin, F., \& Balandier, P. (2008). Influence of Tree Species on Understory Vegetation Diversity and Mechanisms Involved-A Critical Review for Temperate and Boreal Forests. Forest Ecology and Management, 254, 1-15. https://doi.org/10.1016/j.foreco.2007.09.038

Beer, J., Muschler, R., Kass, D., \& Somarriba, E. (1998). Shade Management in Coffee and Cacao Plantations. Agroforestry Systems, 38, 139-164.

https://doi.org/10.1007/978-94-015-9008-2_6

Brown, C. D., \& Boutin, C. (2009). Linking Past Land Use, Recent Disturbance, and Dispersal Mechanism to Forest Composition. Biological Conservation, 142, 1647-1656. 
https://doi.org/10.1016/j.biocon.2009.02.035

Emmanuel, A. B. (2011). Does Taungya Foster Woody Species Diversity in Ghana? A Case of the Afram Head Waters Forest Reserve.

Engida, T. D., \& Teshome, A. J. (2012). The Socio Economic Effects of Community Forest Management: Evidence from Dendi District, Ethiopia. International Affairs and Global Strategy, 4, 15-22.

Faminow, M. D., \& Rodringuez, E. A. (2001). Biodiversity of Flora and Fauna in Shaded Coffee Systems. Report, Montreal: Commission for Environmental Cooperation.

Friis, I. (2009). Floristic Richness and Endemism in the Flora of Ethiopia and Eritrea. In I. Hedberg, I. Friis, \& E. Persson (Eds.), Flora of Ethiopia and Eritrea Vol. 8. General Part and Index to Volumes 1-7 (pp. 33-38). Addis Ababa and Uppsala: The National Herbarium.

Gole, T. W. (2003). Vegetation of the Yayu Forest in SW Ethiopia: Impacts of Human Use and Implications for In-Situ Conservation of Wild Coffea arabica L. Populations. Gottingen: Cuvillier Verlag.

Gole, T. W., \& Senbeta, F. (2008). Sustainable Management and Promotion of Coffee Based Forest in Bale, Ethiopia. Addis Ababa: Bale Eco-Region Sustainable Management Programme SOS Sahel/FARM-Africa.

Gole, T. W., Borsch, T., Denich, D., \& Teketay, D. (2008). Floristic Composition and Environmental Factors Characterizing Coffee Forests in Southwest Ethiopia. Forest Ecology and Management, 255, 2138-2150. https://doi.org/10.1016/j.foreco.2007.12.028

Gole, T. W., Denich, M., Demel, T., \& Vlek, P. L. G. (2002). Human Impacts on Coffea arabica Genetic Pool in Ethiopia and the Need for Its In-Situ Conservation. In J. M. M. Engels, A. H. D. Brown, \& M. T. Jackson (Eds.), Managing Plant Genetic Resources (pp. 237-247). Wallington: CAB International.

https://doi.org/10.1079/9780851995229.0237

Good, L. (2004). Forests Matter, GEF's Contribution to Conserving and Sustaining Forest Ecosystems. Washington DC: Global Environmental Facility.

Heywood, V. H. (1995). Global Biodiversity Assessment (1140 p.). Cambridge: Cambridge University Press. https://doi.org/10.1007/978-94-015-7358-0

Hundera, K., Aerts, R., Fontaine, A., van Mechelen, M., Gijbels, P., Honnay, O., \& Muys, B. (2013). Effects of Coffee Management Intensity on Composition, Structure, and Regeneration Status of Ethiopian Moist Evergreen Afromontane Forests. Environmental Management, 51, 801-811. https://doi.org/10.1007/s00267-012-9976-5

Hylander, K., \& Sileshi, N. (2009). Complementary Roles of Home Gardens and Exotic Tree Plantations as Alternative Habitats for Plants of the Ethiopian Montane Rainforest. Conservation Biology, 23, 400-409. https://doi.org/10.1111/j.1523-1739.2008.01097.x

Komar, O. (2006). Ecology and Conservation of Birds in Coffee Plantations: A Critical Review. Bird Conservation International, 16, 1-23. https://doi.org/10.1017/S0959270906000074

Krebs, C. J. (1999). Ecological Methodology (2nd ed.). Menlo Park, CA: Benjamin Cummings.

Kufa, T. (2006). Eco-Physiological Diversity of Wild Arabica Populations in Ethiopia: Growth, Water Relations and Hydraulic Characteristics along a Climatic Gradient. Gottingen: Cuvillier Verlag.

Kumsa, L., Hylander, K., Gurmessa, D., \& Nemomissa, S. (2016). Patch Area and Current Coffee Management Determine Woody Plant Diversity in Patches of Semi-Forest Cof- 
fee Embedded in an Agricultural Matrix. Global Ecology and Conservation, 8, 230-240. https://doi.org/10.1016/j.gecco.2016.09.012

Laurance, W. F. (2010). Habitat Destruction: Death by a Thousand Cuts. Oxford: Oxford University Press. https://doi.org/10.1093/acprof:oso/9780199554232.003.0005

Likassa, E. (2014). Diversity of Shade Tree Species in Smallholder Coffee Farms of Western Oromia, Ethiopia. African Journal of Geo-Science Research, 3, 1-3.

Magurran, A. E. (1988). Ecological Diversity and Measurement (354 p.). Berlin: Springer. https://doi.org/10.1007/978-94-015-7358-0

Magurran, A. E. (2004). Measuring Biological Diversity(215 p.). Victoria: Blackwell Publishing Company.

Mebrat, W., \& Gashaw, T. (2013). Threats of Woody Plant Species Diversity and Their Conservation Techniques in Ethiopia. European Journal of Botany, Plant Science and Phytology, 3, 10-17.

Mekuria, W., \& Aynekulu, E. (2011). Exclosure Land Management for Restoration of the Soils in Degraded Communal Grazing Lands in Northern Ethiopia. Journal of Land Degradation and Development, 24, 528-538. https://doi.org/10.1002/ldr.1146

Mendez, V. E., Gliessman, S. R., \& Gilbert, G. S. (2007). Tree Biodiversity in Farmer Cooperatives of a Shade Coffee Landscape in Western El Salvador. Agriculture, Ecosystems and Environment, 119, 145-159. https://doi.org/10.1016/j.agee.2006.07.004

Mengist, W., Urgessa, K., Haile, K., \& Kebebew, Z. (2013). Comparative Study of Forest under Participatory Forest Management: A Case of Belete Gera Forest, Southwest Ethiopia. Middle East Journal of Scientific Research, 17, 607-612.

Mittermeier, R. A., Gil, P. R., Hoffman, M., Pilgrim, J., Brooks, T., Mittermeier, C. G., Lamoreux, J., \& da Fonseca, G. A. (2005). Hotspots Revisited: Earth's Biologically Richest and Most Endangered Terrestrial Eco-Regions. Washington DC: Conservation International.

Moguel, P., \& Toledo, V. M. (1999). Biodiversity Conservation in Traditional Coffee Systems of Mexico: A Review. Conservation Biology, 13, 11-21. https://doi.org/10.1046/j.1523-1739.1999.97153.x

Motuma, T., Zebene, A., Mulugeta, L., \& Karltun, E. (2008). Woody Species Diversity in a Changing Landscape in the Southcentral Highlands of Ethiopia. Agriculture, Ecosystems and Environment, 128, 52-58. https://doi.org/10.1016/j.agee.2008.05.001

Myers, N. (2000). Biodiversity Hotspots for Conservation Priorities. Nature, 403, 853-858. https://doi.org/10.1038/35002501

Nigatu, D., Tiki, L., Kewessa, G., \& Datiko, D. (2017). Traditional Coffee Management Practices and Their Effects on Woody Species Structure and Regeneration in Bale Eco-Region, Ethiopia. International Journal of Advanced Research, 5, 591-598. https://doi.org/10.21474/IJAR01/4454

Pant, S., \& Samant, S. S. (2007). Assessment of Plant Diversity and Prioritization of Communities for Conservation in Mornaula Reserve Forests, G.B. Himachal Pradesh: Plant Institute of Himalaya Environment and Development, Himalaya Unit.

Perfecto, I., Vandermeer, J., Mas, A., \& Pinto, S. L. (2005). Analysis Biodiversity, Yield, and Shade Coffee Certification. Ecological Economics, 54, 435-446.

https://doi.org/10.1016/j.ecolecon.2004.10.009

Priess, J. A., Mimler, M., Klein, A. M., Schwarze, S., Tscharntke, T., \& Steffan-Dewenter, I. (2007). Linking Deforestation Scenarios to Pollination Services and Economic Returns in Coffee Agroforestry Systems. Ecological Application, 17, 407-417.

https://doi.org/10.1890/05-1795 
Schmitt, C. B., Senbeta, F., Denich, M., Preisinger, H., \& Boehmer, H. J. (2009). Wild Coffee Management and Plant Diversity in the Montane Rainforest of Southwestern Ethiopia. African Journal of Ecology, 48, 78-86.

https://doi.org/10.1111/j.1365-2028.2009.01084.x

Schmitt, C., \& Grote, U. (2006). Wild Coffee Production in Ethiopia: The Role of Coffee Certification for Forest Conservation. Bonn: German Federal Ministry for Education and Research.

Senbeta, F. (2006). Biodiversity and Ecology of Afromontane Rainforests with Wild Coffea arabica Populations in Ethiopia. Ecology and Development Series 38.

Senbeta, F., \& Denich, M. (2006). Effects of Wild Coffee Management on Species Diversity in the Afromontane Rainforests of Ethiopia. Forest Ecology and Management, 232, 68-74. https://doi.org/10.1016/j.foreco.2006.05.064

Senbeta, F., \& Teketay, D. (2001). Regeneration of Indigenous Woody Species under the Canopies of Tree Plantations in Central Ethiopia. Tropical Ecology, 42, 175-185.

Shannon, C. E., \& Weaver, W. (1948). A Mathematical Theory of Communication. The Bell System Technical Journal, 27, 379-423. https://doi.org/10.1002/j.1538-7305.1948.tb01338.x

Silva, J., Jones, P., Eldridge, W., Thorpe, J., Campbell, E., \& Ohara, M. (2008). Life and Endangered Plants: Conserving Europe's Threatened Flora (pp. 1-2).

Sørensen, T. A. (1948). A Method of Establishing Groups of Equal Amplitude in Plant Sociology Based on Similarity of Species Content, and Its Application to Analyses of the Vegetation on Danish Commons. Kongelige Danske Videnskabernes Selskabs Biologiske Skrifter, 5, 1-34.

Teketay, D. (1999). History, Botany and Ecological Requirements of Coffee. Walia, 20, 28-50.

Tesfaye, K. (2006). Genetic Diversity of Wild Coffea arabica Populations in Ethiopia as a Contribution to Conservation and Use Planning Ecology and Development Series 44.

Tolera, M., Asfaw, Z., Lemenih, M., \& Erik, K. (2008). Woody Species Diversity in a Changing Landscape, Southcentral Ethiopia Highlands. Agriculture Ecosystem and Environment, 128, 52-58. https://doi.org/10.1016/j.agee.2008.05.001

Valencia, V. (2015). The Role of Coffee Agroforestry in the Conservation of Tree Diversity and Community Composition in Native Forests. In Management of Land Use Systems for Enhanced Food Security: Conflicts, Controversies and Resolutions. New York.

Walters, D. J. J., Kotze, D. C., \& O’Connor, T. G. (2006). Impact of Land Use on Vegetation Composition, Diversity, and Selected Soil Properties of Wetlands in the Southern Drakensberg Mountains, South Africa. Wetland Ecology and Management, 14, 329-348. https://doi.org/10.1007/s11273-005-4990-5

Wassie, A., Sterck, F. J., Teketay, D., \& Bongers, F. (2009). Effects of Livestock Exclusion on Tree Regeneration in Church Forests of Ethiopia. Forest Ecology and Management, 257, 765-772. https://doi.org/10.1016/j.foreco.2008.07.032

Wilson, B. J., Wells, E. C. T., Trueman, C. I., Jones, G., Atkinson, D. M., Crawley, J. M., Doddi, E. M., \& Silvertown, J. (1996). Are There Assembly Rules for Plant Species Abundance? An Investigation in Relation to Soil Resources and Successional Trends. Journal of Ecology, 84, 527-538. https://doi.org/10.2307/2261475

Yadessa, A., Burkhardt, J., Denich, M., Woldemariam, T., Bekele, E., \& Goldbach, H. (2008). Effect of Different Indigenous Shade Trees on the Quality of Wild Arabica Coffee in the Afromontane Rainforests of Ethiopia. 


\section{Appendices}

Table A1. Woody species composition of natural forest in the study site ( $\mathrm{T}=$ Tree, $\mathrm{TS}=$ Tree/Shrub).

\begin{tabular}{|c|c|c|c|c|c|}
\hline No. & Species Name & Family Name & Local Name & $\begin{array}{l}\text { Life } \\
\text { form }\end{array}$ & $\begin{array}{l}\text { Absolute } \\
\text { Frequency }\end{array}$ \\
\hline 1. & Acalypha volkensii pax & Euphorbiaceae & Fuho & TS & 25 \\
\hline 2. & Apodytes acutifolia & Icacinaceae & Mewa & $\mathrm{T}$ & 30 \\
\hline 3. & Avophaylus abyssinica & Sapindaceae & Obora & $\mathrm{T}$ & 5 \\
\hline 4. & Bersama abyssinica Fresen. & Melianthaceae & Horoqa & $\mathrm{T}$ & 15 \\
\hline 5. & Buddleia polystachya & Loganiaceae & Dhadhatu & $\mathrm{T}$ & 50 \\
\hline 6. & Calpurnia aurea (Ait.) Benth. & Fabaceae & Cekata & S & 30 \\
\hline 7. & Capparis tomentosa & Capparidaceae & Arangama & S & 20 \\
\hline 8. & Carissa spinarum $\mathrm{L}$. & Apocyanceae & Hagamsa & S & 20 \\
\hline 9. & Cassipourea malosana (Baker) Alston & Rhizophoraceae & Tilo & $\mathrm{T}$ & 65 \\
\hline 10. & Celtis africana Burm.f. & Ulmaceae & Mataqoma & $\mathrm{T}$ & 100 \\
\hline 11. & Citrus aurantium & Rutaceae & Arbo/Irba & TS & 55 \\
\hline 12. & Coffea arabica $L$. & Rubiaceae & Buna & S & 60 \\
\hline 13. & Crotolaria agatiflora Schweinf. Sub.sp. Erlangeri Bak. F. & Fabaceae & Shashamane & S & 10 \\
\hline 14. & Croton macrostachyus Del. & Euphorbiaceae & Makanisa & $\mathrm{T}$ & 25 \\
\hline 15. & Diospyros abyssinica (Hiern) F. White & Ebenaceae & Loko adi & TS & 90 \\
\hline 16. & Diospyros mespiliformis Hochst. Ex A.DC & Ebenaceae & Loko guracha & $\mathrm{T}$ & 95 \\
\hline 17. & Dobera glabra & Salvadoraceae & Hara & TS & 10 \\
\hline 18. & Ehretia cymosa Thonn. & Boraginaceae & Ulaga & $\mathrm{T}$ & 60 \\
\hline 19. & Euclea racemosa Murr.subsp. schimperi (A. DC.) White & Ebenaceae & Miesa & $\mathrm{T}$ & 5 \\
\hline 20. & Fagaropsis angolensis (Engl.) Milne & Rutaceae & Sisa & $\mathrm{T}$ & 15 \\
\hline 21. & Ficus sur Forssk. & Moraceae & Harbu & $\mathrm{T}$ & 5 \\
\hline 22. & Ficus thonningii Blume & Moraceae & Dembi & $\mathrm{T}$ & 5 \\
\hline 23. & Filicium decipiens (Wight \& Am.) Thw. & Sapindaceae & Cana & $\mathrm{T}$ & 75 \\
\hline 24. & Galiniera saxifraga ( $G$. coffeoides) & Rubiaceae & Jaldae & $\mathrm{T}$ & 65 \\
\hline 25. & Maytenus gracilipes (Welw.ex Oliv.) Exell subsp. Arguta (Loes.) & Celastraceae & Kombolcha & TS & 30 \\
\hline 26. & Mimusops kummel A. DC. & Sapotaceae & Qolati & $\mathrm{T}$ & 20 \\
\hline 27. & Myrsine africana & Myrsinaceae & Baco/qacama & S & 5 \\
\hline 28. & Ocotea kenyensis (Chiov.) Robyns \& Wilczek & Lauraceae & Gigicha & $\mathrm{T}$ & 55 \\
\hline 29. & Olea capensis L. ssp. Macrocarpa (C. H. Wright) Verdc. & Oleaceae & Segida & $\mathrm{T}$ & 15 \\
\hline 30. & Olea capensis subsp. hochstetteri (Bak.) P.S. Friis & Oleaceae & Onoma & $\mathrm{T}$ & 65 \\
\hline 31. & Olea welwitschii (Knobl.) Gilg \& Schellenb. & Oleaceae & Gagama & $\mathrm{T}$ & 65 \\
\hline 32. & Podocarpus falcatus (Thunb.) R. B. ex. Mirb & Podocarpaceae & Birbirsa & $\mathrm{T}$ & 95 \\
\hline 33. & Polyscias fulva (Hiern) Harms & Araliaceae & Koriba & $\mathrm{T}$ & 5 \\
\hline 34. & Psydrax schimperiana (A. Rich.) Bridson & Rubiaceae & Galo & $\mathrm{T}$ & 65 \\
\hline 35. & Rhamnus prinoides L. Herit. & Rhamnaceae & Gesho & TS & 45 \\
\hline 36. & Rhus ruspolii Engl. & Anacardiaceae & Hirqe & TS & 20 \\
\hline 37. & Rothmannia urcelliformis (Hiern.) Robyns & Rubiaceae & Bulala & $\mathrm{T}$ & 60 \\
\hline 38. & Schrebera alata (Hochst.) Welw. & Oleaceae & Dhamae & $\mathrm{T}$ & 10 \\
\hline 39. & Strychnos mitis S. Moore & Loganiceae & Mulka & $\mathrm{T}$ & 95 \\
\hline 40. & Strychnos spinosa & Myrtaceae & Gotu & $\mathrm{T}$ & 5 \\
\hline 41. & Syzygium guineense & Myrtaceae & Badessa & $\mathrm{T}$ & 40 \\
\hline 42. & Teclea nobilis Del. & Rutaceae & Hadhesa & $\mathrm{T}$ & 70 \\
\hline 43. & Terminalia laxilora & Combretaceae & Dabaqa & $\mathrm{T}$ & 30 \\
\hline & Trema guineensis (Schumach. \& Thonn.) & Ulmaceae & Hagala & $\mathrm{T}$ & 5 \\
\hline 45. & Vepris dainellii (Pichi-Serm.) Kokwaro & Rutaceae & Arabe & TS & 60 \\
\hline & Vernonia leopoldi (Sch. Bip. ex walp.) Vatke & Astraceae & Reji & S & 10 \\
\hline 47. & Warburgia ugandensis Sprague & Canellaceae & Befti & $\mathrm{T}$ & 60 \\
\hline
\end{tabular}


Table A2. Woody species composition of forest coffee in the study site $(\mathrm{T}=$ Tree, $\mathrm{TS}=\mathrm{Tree} / \mathrm{Sh} \mathrm{rub})$.

\begin{tabular}{|c|c|c|c|c|c|}
\hline No. & Species Name & Family Name & Local Name & $\begin{array}{l}\text { Life } \\
\text { form }\end{array}$ & $\begin{array}{l}\text { Absolute } \\
\text { Frequency }\end{array}$ \\
\hline 1. & Allophylus abyssinicus & Sapindaceae & Arjo & $\mathrm{T}$ & 10 \\
\hline 2. & Apodytes acutifolia & Icacinaceae & Mewa & $\mathrm{T}$ & 5 \\
\hline 3. & Avophaylus abyssinica & Sapindaceae & Obora & $\mathrm{T}$ & 5 \\
\hline 4. & Bersama abyssinica Fresen. & Melianthaceae & Horoqa & S & 25 \\
\hline 5. & Buddleia polystachya & Loganiaceae & Dhadhatu & $\mathrm{T}$ & 5 \\
\hline 6. & Calpurnia aurea (Ait.) Benth. & Fabaceae & Cekata & S & 15 \\
\hline 7. & Cassipourea malosana (Baker) Alston & Rhizophoraceae & Tilo & $\mathrm{T}$ & 45 \\
\hline 8. & Celtis africana Burm.f. & Ulmaceae & Mataqoma & $\mathrm{T}$ & 95 \\
\hline 9. & Citrus aurantium & Rutaceae & Arbo/Irba & TS & 20 \\
\hline 10. & Coffea arabica $L$. & Rubiaceae & Buna & S & 100 \\
\hline 11. & Cordia africana Lam. & Boraginaceae & Wadessa & $\mathrm{T}$ & 5 \\
\hline 12. & Crotolaria agatiflora Schweinf. Sub.sp. Erlangeri Bak. F. & Fabaceae & Shashamane & S & 15 \\
\hline 13. & Croton macrostachyus Del. & Euphorbiaceae & Makanisa & $\mathrm{T}$ & 50 \\
\hline 14. & Diospyros abyssinica (Hiern) F. White & Ebenaceae & Loko adi & TS & 80 \\
\hline 15. & Diospyros mespiliformis Hochst. Ex A.DC & Ebenaceae & Loko guracha & $\mathrm{T}$ & 85 \\
\hline 16. & Ehretia cymosa Thonn. & Boraginaceae & Ulaga & $\mathrm{T}$ & 50 \\
\hline 17. & Fagaropsis angolensis (Engl.) Milne & Rutaceae & Sisa & $\mathrm{T}$ & 10 \\
\hline 18. & Ficus sycomorus & Moraceae & Lugo & $\mathrm{T}$ & 5 \\
\hline 19. & Filicium decipiens (Wight \& Am.) Thw. & Sapindaceae & Cana & $\mathrm{T}$ & 25 \\
\hline 20. & Galiniera saxifraga ( $G$. coffeoides) & Rubiaceae & Jaldae & $\mathrm{T}$ & 50 \\
\hline 21. & Mimusops kummel A. DC. & Sapotaceae & Qolati & $\mathrm{T}$ & 35 \\
\hline 22. & Ocotea kenyensis (Chiov.) Robyns \& Wilczek & Lauraceae & Gigicha & $\mathrm{T}$ & 25 \\
\hline 23. & Olea capensis subsp.hochstetteri (Bak.) P.S. Friis & Oleaceae & Onoma & $\mathrm{T}$ & 75 \\
\hline 24. & Olea welwitschii (Knobl.) Gilg \& Schellenb. & Oleaceae & Gagama & $\mathrm{T}$ & 5 \\
\hline 25. & Podocarpus falcatus (Thunb.) R. B. ex. Mirb & Podocarpaceae & Birbirsa & $\mathrm{T}$ & 95 \\
\hline 26. & Polyscias fulva (Hiern) Harms & Araliaceae & Koriba & $\mathrm{T}$ & 10 \\
\hline 27. & Psydrax schimperiana (A. Rich.) Bridson & Rubiaceae & Galo & $\mathrm{T}$ & 55 \\
\hline 28. & Rhus ruspolii Engl. & Anacardiaceae & Hirqe & TS & 30 \\
\hline 29. & Rothmannia urcelliformis (Hiern.) Robyns & Rubiaceae & Bulala & $\mathrm{T}$ & 40 \\
\hline 30. & Schrebera alata (Hochst.) Welw. & Oleaceae & Dhamae & $\mathrm{T}$ & 5 \\
\hline 31. & Strychnos mitis $S$. Moore & Loganiceae & Mulka & $\mathrm{T}$ & 85 \\
\hline 32. & Syzygium guineense & Myrtaceae & Badessa & $\mathrm{T}$ & 35 \\
\hline 33. & Teclea nobilis Del. & Rutaceae & Hadhesa & $\mathrm{T}$ & 25 \\
\hline 34. & Terminalia laxilora & Combretaceae & Dabaqa & $\mathrm{T}$ & 15 \\
\hline 35. & Trema guineensis (Schumach. \& Thonn.) Ficalho & Ulmaceae & Hagala & $\mathrm{T}$ & 5 \\
\hline 36. & Trichilia emetica ( T. roka) & Meliaceae & Anonu & $\mathrm{T}$ & 5 \\
\hline 37. & Vepris dainellii (Pichi-Serm.) Kokwaro & Rutaceae & Arabe & TS & 20 \\
\hline 38. & Vernonia leopoldi (Sch. Bip. ex walp.) Vatke & Astraceae & Reji & S & 15 \\
\hline 39. & Warburgia ugandensis Sprague & Canellaceae & Befti & $\mathrm{T}$ & 55 \\
\hline
\end{tabular}

